Nippon Suisan Gakkaishi $\quad$ 80(3), 349-359 (2014)

\title{
飼育したケガニ幼生の走光性，鉛直分布，体密度と 外部形態の発育に伴う変化
}

\author{
市川 卓, ${ }^{2}$ 那波洋子, ${ }^{2}$ 浜 崎活 幸, ${ }^{2 *}$ 村上 恵 祐 $^{3}$ \\ (2014 年 1 月 7 日受付, 2014 年 2 月 13 日受理) \\ 1独水産総合研究センター北海道区水産研究所厚岸庁舎, \\ 2 東京海洋大学大学院海洋生物資源学部門, \\ 3 蛍水産総合研究センター本部経営企画部
}

Ontogenetic changes of phototaxis, vertical distribution, body density and external morphology during larval development in the horsehair crab Erimacrus isenbeckii reared in the laboratory

\section{TAKASHI ICHIKAWA, ${ }^{1}$ YoKO NAWA, ${ }^{2}$ KATSUYUKI HAMASAKI ${ }^{2 *}$ AND KEISUKE MURAKAMI ${ }^{3}$}

\begin{abstract}
${ }^{1}$ Akkeshi Laboratory, Hokkaido National Fisheries Research Institute, Fisheries Research Agency, Akkeshi, Hokkaido 088-1108, 2Department of Marine Biosciences, The Graduate School of Marine Science and Technology, Tokyo University of Marine Science and Technology, Minato, Tokyo 108-8477, ${ }^{3}$ General Planning and Coordination Department, Headquarters, Fisheries Research Agency, Yokohama, Kanagawa 220-6115, Japan
\end{abstract}

The larval sinking phenomenon is a cause of larval mass mortality during seed production of the horsehair crab Erimacrus isenbeckii. As a basis for developing larval rearing techniques to prevent this phenomenon, we examined the larval phototaxis, vertical distribution, body density and external morphology such as carapace spines, which may provide drag force while larvae are sinking in seawater. Larvae showed positive phototaxis in the first zoeal stage, and showed strengthened negative phototaxis after the second zoeal stage. Higher incidences of negative phototactic behavior were recorded at longer wavelengths of more than $620 \mathrm{~nm}$ in all larval stages. Newly hatched larvae floated in the vertical test chamber, but they tended to sink in the chamber one day after hatching. Larval body density was greater than the specific gravity of the seawater. The length of carapace spines tended to decrease with larval growth. The horsehair crab larvae thus showed a behavioral habit that makes them sink in seawater under the light condition. Further studies should examine methods for rearing horsehair crab larvae under dark conditions or under light of longer wavelengths from the bottom of the vertical chamber.

キーワード：ケガニ，種苗生産，浮遊性，幼生

ケガニ Erimacrus isenbeckii は北海道に打ける重要な 水産資源であり, 1930 年代から缶詰の原料として利用 され始め，現在は主に煮ガニや活カニとして流通してい る。北海道に打けるケガニの漁獲量は 1950 年代に 27,000トン台を記録してピークに達したが，その後急 激に減少したため, 資源回復を図るために漁業規制等の 対策が講じられてきた。1) しかし，その漁獲量は 2,000 トン前後と低く推移したため, ${ }^{2)}$ より積極的な資源増殖 方策として種苗放流が計画され，種苗生産技術開発が行 われてきた。3,4)
ケガニ幼生はゾエア 5 齢期, メガロパ 1 期を経て第 1 齢稚ガニへ脱皮・成長する。 5 -7) 本種幼生の飼育はビー カーなどの小型容器では比較的容易であり, メガロパま での生残率は $80 \%$ に達するが, ${ }^{5-7)}$ 大型水槽では大量の ゾエア幼生が水槽底に沈下・蝟集した後に死亡する現象 が頻発し， ${ }^{3,4)}$ 未だ種苗生産技術は確立されていない。飼 育中のゾエア幼生が水槽底に沈下した後に死亡する沈降 死現象はズワイガニChionoecetes opilio の種苗生産でも 知られて抢り, 水槽底に堆積した有機物に幼生が接触す ることで細菌感染症に罹病しやすくなる可能性が指摘さ

* Tel : 81-3-5463-0538. Fax : 81-3-5463-0538. Email : hamak@kaiyodai.ac.jp 
れている。8,9)

一般に甲殼類幼生の走光性は, その水中に打ける鉛直 分布に大きな影響を及ぼすことが知られている。10-17) 著 者らは前報18)に扔いて, ケガニ幼生を透明ポリカーボ ネート製と黒色ポリエチレン製の水槽で飼育し，幼生の 沈降々発育状況を調べた。その結果, 昼間の光環境は水 槽種類で大きく異なり, 光量子束密度（以下, 光量）は 黒色水槽では水深に比例して減少したが，透明水槽では 中層と下層で大きい值を示した。また，水槽の下層に分 布した幼生の割合（沈降率）は透明水槽で高く，幼生の 発育も遅延した。さらには, 沈降率は昼間より夜間の值 が低く, 水槽間の差が縮小した。このようなケガニ幼生 の水槽内分布の違いは幼生の走光性に起因するものと考 えられ, 今後は幼生の走光性の個体発生について検討 し，走性を惹起する環境を明らかにする必要があること を指摘した。

沈降死はカ二類幼生の他に, カンパチ Seriola dumerili, 19,20) クロマグロ Thunnus orientalis, ${ }^{21)}$ クエ Epinephelus bruneus ${ }^{22)}$ などの魚類種苗生産においても発 生することが知られている。仔魚の沈降は海水比重, 体 密度および通気などによる飼育水の流動と関連して掞 り, 19-22) 沈降速度は体密度に比例する。21) また, プラン クトンの体表面の突起物は, 抗力（沈下抵抗）の増大に 寄与することが知られている。23-25) ケガニ幼生の浮遊性 も体密度や外部形態から影響を受けているものと考えら れるが，体密度に関する知見はなく，また発育に伴う外 部形態の変化を定量的に解析した報告はない。

本研究ではケガニ種苗生産に抢ける幼生の沈降死防除 技術を開発する基礎として，ケガニ幼生を飼育し，異な る光量と波長に対する走光性, 明暗条件下に抢いた容器 内での鉛直分布, 体密度と外部形態の発育に伴う変化を 調査した。

\section{材料と方法}

幼生の飼育 実験は 2007 年と 2008 年に独水産総合 研究センター北海道区水産研究所厚岸庁舎で実施した。 抱卵雌の入手・養成方法は前報18)に記載したと打りで ある。幼生は親ガニ養成水槽内に抢いて日没後にふ化 し, 養成水槽の排水を $500 \mathrm{~L}$ 水槽内に導いて回収し た。な打本研究では, 子化当日の日没から翌日の日没前 までを 0 日齢とし，その後は日没を起点として幼生の 日齢を加算することとした。ふ化の翌朝にあたる 2007 年 4 月 11 日抢よび 2008 年 4 月 15 日に, それぞれ $2 \mathrm{~L}$ ポリエチレン白色ビーカー 8 個に活発に遊泳する第 1 齢ゾエア（以下，Z1）を65 個体ずつ収容した。飼育個 体数は, 第 5 齢ゾエア $(Z 5)$ では 50 個体, メガロパ (MG) では 30 個体程度, 第 1 齢稚ガニ（C1）では 510 個体程度に減じた。また, MG と C1では共食いを
軽減するために，脱皮日ごとに別のビーカーで飼育した。 飼育に用いた海水は, 砂ろ過した後に $5 \mu \mathrm{m}$ のカート リッジフィルター（ポリプロピレンワインドカートリッ ジフィルター, ADVANTEC) で再ろ過したもので, そ の塩分抢よび比重の平均值は 33.7 および 1.025 であっ た。飼育水温はウォーターバス方式で調節し, 子化幼生 の收容時には $2-3^{\circ} \mathrm{C}$, 翌日には本種幼生の適正飼育温度 である $12^{\circ} \mathrm{C}^{6}$ ) で昇温させ, 以降 $12^{\circ} \mathrm{C}$ を維持した。各 ビーカーへの通気は, 先端の口径を通常の 2 分の 1 以 下に加工したパスッールピペット 1 本を用い, 微量に 行った。ウォーターバスは屋内の自然光下に設置し, 光 量を水中光量子センサー（LI-192SA, LI-COR）打よび データロガー (LI-1400, LI-COR) を用いて, ウォーター バスの四方で 9 時, 13 時, 17 時 30 分頃に測定したと ころ, 晴天時ではそれぞれ 2.9-19.1 $\mu \mathrm{mol} \mathrm{m}^{-2} \mathrm{~s}^{-1}, 4.4-$ $9.8 \mu \mathrm{mol} \mathrm{m}^{-2} \mathrm{~s}^{-1}, 0.6-7.9 \mu \mathrm{mol} \mathrm{m}^{-2} \mathrm{~s}^{-1}$, 雨天時ではそ れぞれ $1.3-5.1 \mu \mathrm{mol} \mathrm{m}^{-2} \mathrm{~s}^{-1}, 2.6-2.8 \mu \mathrm{mol} \mathrm{m}^{-2} \mathrm{~s}^{-1}$, 0.2-3.0 $\mu \mathrm{mol} \mathrm{m}^{-2} \mathrm{~s}^{-1}$ であった。䬣料には北米産アルテ ミアArtemia sp. を用い, $28^{\circ} \mathrm{C}-24$ 時間でふ化させた。

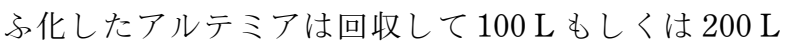
アルテミアふ化器に 100 個体 $/ \mathrm{mL}$ となるように収容 し, 市販の栄養強化剂（スーパーカプセルパウダー, ク

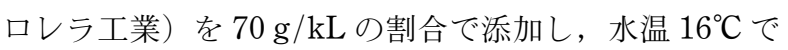
16-20 時間栄養強化した。給餌密度は Z1 と第 2 齢ゾエ ア $(\mathrm{Z} 2)$ では 2 個体 $/ \mathrm{mL}$, 第 3 齢 $(\mathrm{Z} 3)$ と第 4 齢ゾエ ア (Z4) では 2.5 個体 $/ \mathrm{mL}, \mathrm{Z} 5$ 以降では 3 個体 $/ \mathrm{mL}$ と した。さらに MGとC1にはアサリRuditapes philippinarumの小片を啇宜与えた。

幼生は毎日午前中に, 新しい海水を入れた後にウォー ターバスに設置して調温したビーカーに, 石英ガラス管 （長さ $30 \mathrm{~cm}$, 内径 $6 \mathrm{~mm}$ もしくは $8 \mathrm{~mm}$ ) の先端にゴ 么球を取り付けたピペットを用いて移送した。その際に は齢期を確認しながら生残個体を計数するとともに, 死 亡個体を除去した。また, 飼育水には幼生への細菌感染 を防止するためにストレプトマイシン硫酸塩（Sigma） を $2 \mathrm{ppm}$ 濃度で添加した。

走光性 全ての実験は暗室内（組み立て暗室, 森本化 成）で行った。幼生の走光性は, Hamasaki et al. ${ }^{17)}$ がヤ シガニBirgus latro 幼生の走光性を調べた方法に準拠 し, 水平に設置した容器で人工光源を用いて調べた。実 験容器は幅 $12 \mathrm{~cm}$, 高さ $10 \mathrm{~cm}$, 長さ $100 \mathrm{~cm}$ の長方形 で, 光の反射を抑える艶消しの黒色アクリル樹脂で制作 し, 短側面の片側は透明アクリル板とした。容器の底に は $10 \mathrm{~cm}$ 間隔で目盛を書き込んだ。また容器の上面全 体を黒色アクリル製の蓋で, 短側面の透明アクリル板の 外側を黒色アクリル板で遮光できる仕様とした。容器内 には飼育水と同じ水温と塩分の海水を入れた。光源装置 として太陽光に近い波長組成を示す $180 \mathrm{~W}$ メルハラ 
イドファイバー照明装置 (Luminar Ace, HAYASHI) を用い, 容器の透明な短側面から光を水平に照射した。 光量別実験では, 水平容器中央での光量子束密度が $0.0031,0.031,0.31,3.1,31,310 \mu \mathrm{mol} \mathrm{m}^{-2} \mathrm{~s}^{-1}$ の 6 照射 区，および光を照射せずに短側面側に遮光板を挿入した 暗黑区 $\left(0 \mu \mathrm{mol} \mathrm{m}^{-2} \mathrm{~s}^{-1}\right)$ の計 7 処理区を設定した。ま た, 波長別実験では, 容器中央での光量子束密度を 1.5 $\mu \mathrm{mol} \mathrm{m}{ }^{-2} \mathrm{~s}^{-1}$ に調整し, 波長を 400-660 $\mathrm{nm}$ の範囲で $20 \mathrm{~nm}$ 間隔とした 14 照射区, 波長無調整の光照射区お よび暗黒区の計 16 処理区を設定した。光量と波長は ND フィルターとバンドパスフィルター (Newport) で 調整し, 光量は前述の水中光量子センサーとデータロ ガーで測定した。

光量別実験には 2007 年に飼育した幼生を用い, Z1 $(0,1,3,5$ 日齢)，Z2（7, 10 日齢），Z3 (11, 13 日齢)， Z4 (16，19，20 日齢)，Z5 (22，24，26，28 日齢), MG $(31,32,35,36,40,41,45,46,49,50$ 日齢）打よび C1 (50, 51 日齢) の昼間に調査した。なお，C1 では供試尾 数に限りがあったことから，暗黒区と 3 照射区 $\left(0.0031,31,310 \mu \mathrm{mol} \mathrm{m}^{-2} \mathrm{~s}^{-1}\right)$ で実施した。実験は, 各日齢の各処理区で Z1-Z5 は 2 回 $\left(0.0031 \mu \mathrm{mol} \mathrm{m}^{-2}\right.$ $\mathrm{s}^{-1}$ の $\mathrm{Z} 1$ のみ 1 回), $\mathrm{MG}$ と $\mathrm{C} 1$ では 1 回, 合計 287 回

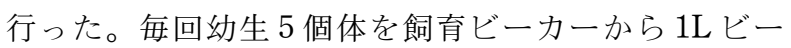
カーに移し, 実験容器中央に設置した内径 $5 \mathrm{~cm}$ の透明 アクリルパイプ内に静かに収容し，1 分ほど静置した。 その後, アクリルパイプと光源側の付属黒色板を同時に 外し,さらに上部の蓋を閉めた。蓋を閉めてから 10 分 後に容器内部を $10 \mathrm{~cm}$ 間隔の 10 区画に区切る櫛状の遮 蔽枠を入れ, 各区画内の幼生を計数した。1 回の試行が 終了すると，実験海水を新しいものに入れ替えた。使用 した幼生は同日の実験には再使用しなかったが, 飼育個 体数に限りがあったことから, 実験終了後に飼育容器に 戻し，翌日以降の実験に再利用した。

波長別実験には2008年に飼育した幼生を用い，Z1（0 (宁化の直後と翌日), 1, 3, 5 日齢), Z2 (7, 9 日齢), Z3 (12, 14 日齢), Z4 (17, 19, 21 日齢), Z5 (23, 25, 27 日齢), MG (30, 31, 35, 36, 41, 42, 45, 46 日齢) 打よ びC1（50 日齢）の昼間に調査した。なお， MGの 30 , 35，41，45 日齢には暗黒，波長無調整抢よび 400-580 $\mathrm{nm}$ の処理区を試行し, $\mathrm{MG}$ の 31, 36, 42, 46 日齢には暗 黒, 波長無調整掞よび 600-660 nm の処理区を試行し た。実験は各日齢の各処理区で 5 個体の幼生を用いて 1 回行い, 合計 328 回試行した。その他の実験方法は光 量別実験に従った。

鉛直分布 実験容器は, 内径 $5 \mathrm{~cm}$, 高さ $45 \mathrm{~cm}$ の透 明アクリル製パイプを縦型に置き, 底を艶消しの黒色ア クリル板としたもので, 容器の側面には底面から $5 \mathrm{~cm}$ 間隔で目盛を付し，底面を $0 \mathrm{~cm}$, 水面を $40 \mathrm{~cm}$ として
計 8 区画に区分した。実験区として，上面より光を照 射する区（水面で $3.1 \mu \mathrm{mol} \mathrm{m}^{-2} \mathrm{~s}^{-1}$ ) と暗黒区を設定し た。実験容器は黒色アクリル製遮光箱に入れ, 遮光箱の 上面中央抢よび長側面の 1 面は開閉できる仕様とした。

実験には 2008 年に飼育した幼生を用い，Z1（0（子 化の直後と翌日), 2,4 日齢), Z2 (6, 8, 10 日齢), Z3 (11, 13， 15 日齢)，Z4（16, 18, 20 日齢），Z5（22，24， 26, 28日齢）抢よび MG（29，31，34，39，44，49日齢）の 昼間に調査した。また，Z2 以降には $8,13,18,24,31$ 日 齢の夜間（19：00 以降）にも同様の実験を行った。幼 生 1 個体を実験容器水面から静かに投入し, 光照射区 では遮光箱上面中央から光を入射し, 5 分後に幼生が位 置する区画を記録した。暗黒区では遮蔽箱で光を遮断し， 5 分後に遮光箱の長側面の 1 面を開けて, 小型ハンディ ライトを用いて素早く幼生が位置する区画を特定した。 1 日の実験には各条件とも 10 個体を用いた。その他の 実験方法は光量別実験に従った。

沈降速度と体密度 幼生の体密度は, 坂本 $5^{21)}$ がク ロマグロ仔魚の体密度測定に用いた方法, すなわち塩分 の異なる海水 2 種類を重層したメスシリンダー中に測 定対象を自由落下させ, その沈降速度比から算出する方 法により測定した。実験は室温を $12^{\circ} \mathrm{C} に$ 設定したプレ 八ブ式恒温室内で行い, 使用した海水の水温, 塩分抢よ び比重は, それぞれ標隼温度計で校正したアルコール温 度計, 海水濃度屈折計（モデル 135A, ATAGO）抢よ び赤沼式海水用比重計（横田計器製作所）を用いて測定

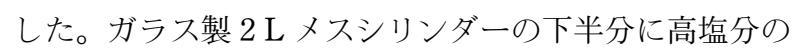
海水 (0-5 日齢, 比重 $1.025 ; 7-10$ 日齢, 1.028-1.033; 12-29 日齢，1.033-1.040；30 日齢以降，1.038-1.050) を入れ，その上に低塩分の海水（0-5 日齢， $1.007-$ $1.015 ; 7-10$ 日齢, 1.006-1.007；12-29 日齢, 1.007 ; 30 日齢以降，1.007-1.014）を下層と混合しないように 静かに注入し, 重層した 2 層を形成した。この際, 比 重が 1.025 以上の高塩分の海水は飼育で使用した砂万過 海水に人工海水の素（マリンソート，ロート製薬）を添 加して作成した。まず，幼生をカルバミン酸エチル （Sigma） $0.4 \mathrm{M}$ 水溶液に 5 分間浸漬して麻醉した後， 1 個体ずつメスシリンダー上部より静かに投入した。次い で, 幼生が頭胸甲前面を下にして一定の姿勢で自由落下 しているのを確認した後, 単位距離当たりの沈降時間を 計測した。測定した沈降時間から沈降速度 $\left(\mathrm{mm} \mathrm{s}^{-1}\right)$ を算出し, 上層と下層での速度比から次式を用いて体密 度 $\left(\mathrm{g} \mathrm{cm}^{-3}\right)$ を求めた。

$$
\rho f=\frac{V 1 \cdot v 1 \cdot \rho 2-V 2 \cdot v 2 \cdot \rho 1}{V 1 \cdot v 1-V 2 \cdot v 2}
$$

ここで, $\rho f$ は幼生の体密度 $\left(\mathrm{g} \mathrm{cm}^{-3}\right), V 1$ は上層, $V 2$ は下層での沈降速度 $\left(\mathrm{mm} \mathrm{s}^{-1}\right), v 1$ は上層, $v 2$ は下層 の海水の粘性率, $\rho 1$ は上層, $\rho 2$ は下層の海水の比重を 
表す。海水の粘性率は, 塩素量（塩分からの換算値）と 水温から Miyake and Koizumi26) より求めた。なお，Z2 以降の幼生の通常海水（比重 1.025）中に抢ける沈降速 度は，別途ガラス製 $200 \mathrm{~mL}$ メスシリンダーを用いて測 定した。

実験には 2007 年に飼育した幼生を用い，Z1（0（ふ 化直後)，1，2，4 日齢），Z2（6, 9 日齢），Z3 (10, 12， 14 日齢)，Z4 (15, 17, 19 日齢), Z5 (21, 23, 25, 27 日 齢), $\mathrm{MG}(29 ， 36 ， 39 ， 44 ， 50$ 日齢) 抢よび $\mathrm{C} 1$ (49 日齢) において, 各日齢 10 個体を用いて調查した。幼生に は, 子化直後を除き, 実験の 3 時間前に新規給䬣して 拱慨させた。実験に使用した幼生は再飼育しなかった。

外部形態 2008 年に飼育した幼生のうち, 各齢期へ 脱皮した当日の幼生 10 個体を $5 \%$ 中性ホルマリンで固 定し， 24 時間後に $70 \%$ エタノールで置換・保存した。 各齢期とも 5 個体について, 以下に示す体サイズ，お よび遊泳能力と沈下抵抗に関わると考えられる遊泳毛 数, 遊泳毛長, 体各部の棘や突起長などを計測した (Fig. 1)。まず，実体顕微鏡下で接眼マイクロメーター を用い, 甲長 (Fig. 1 中の番号 1, 以下同様), 甲幅 (2), 甲高 (3), 側棘間長 (4), 背額棘間長 (5), 第 2
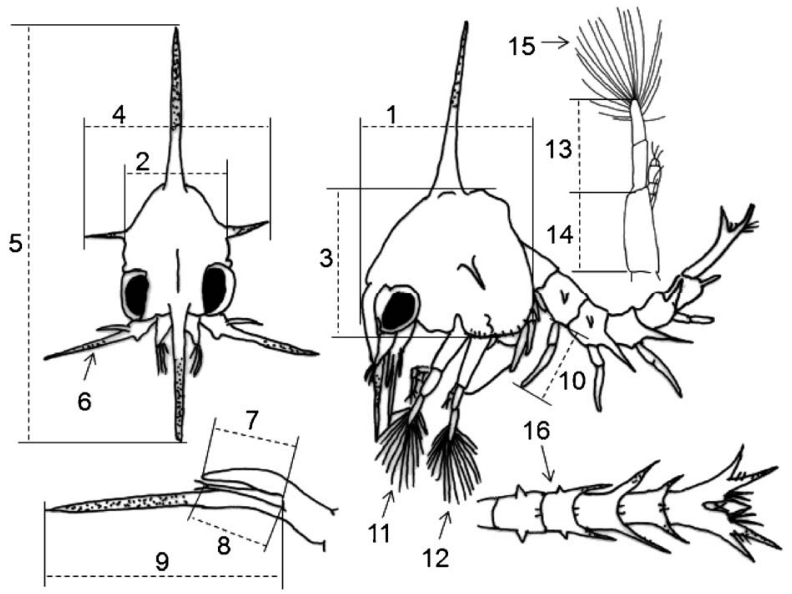

Fig. 1 Schematic illustration of zoea of the horsehair crab, showing the morphological features measured. 1 , carapace length; 2 , carapace width; 3 , carapace height; 4, length between tips of lateral spines; 5 , length between tips of dorsal and ventral spines; 6 , antenna; 7 , length of antennal endopod; 8, length of antennal exopod; 9 , length of propodal process of antenna; 10, length of pleopod bud; 11, first maxilliped; 12 , second maxilliped; 13 , length of maxilliped exopod; 14, length of maxilliped basis; 15, number and length of natatory setae of maxilliped; 16 , whole dorsal area of abdomen. The total length of lateral spines was calculated by subtracting the length of feature 2 from the length of feature 4 . The total length of dorsal and ventral spines was calculated by subtracting the length of feature 3 from the length of feature 5 .
触角（6）の内肢長（7）, 外肢長（8） と原節棘状突起 長 (9)，抢よび腹肢原基長（10）を測定した。このう ち, 側棘間長より甲幅を, また背額棘間長より甲高を差 し引くことにより,それぞれ側棘長と背額棘長を求め た。また, 第 2 触角の各測定値を足し合わせて触角長 とした。次いで, 各個体から第 1 䫈脚（11）および第 2 顎脚（12）を解剖して取り外し，それらの外肢長（13） と基節長（14）を測定した。また, 取り外した第 1 顎 脚抢よび第 2 顎脚の外肢先端部の遊泳毛と腹部全体に カバーガラスを被せ, 背面よりデジタルカメラ（DSVi1, ニコン) で写真撮影した。その画像について, 画 像解析ソフトウェア Image Pro Plus（日本ローパー） を用いて, 各顎脚の遊泳毛（15）の数と全遊泳毛の長 さ(総遊泳毛長), 腹部の突起状部位を含めた全面積 (16) を計測した。

データ解析 統計的検定には統計解析ソフトウェア $\mathrm{R}^{28)}$ を用い，有意水準はすべての検定で $5 \%$ に設定し た。走光性実験の暗黒区では, 幼生は収容した容器中央 付近の光源側と反光源側のそれぞれ 2 区画, 特に中央

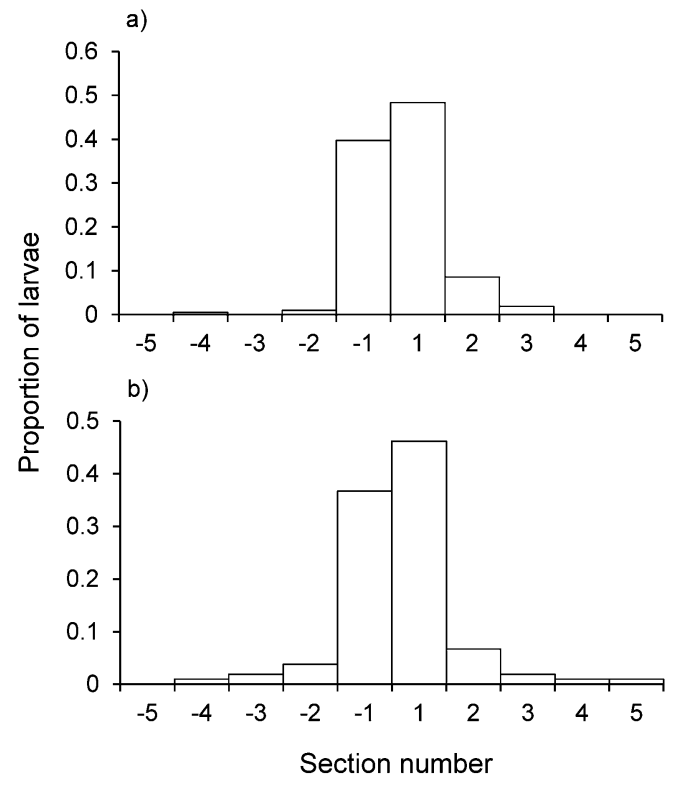

Fig. 2 Proportion of the horsehair crab larvae observed within the respective sections of the horizontal test chamber under the dark condition in the light intensity experiment (a) and the light wavelength experiment (b). The test chamber was marked at $10-\mathrm{cm}$ intervals on the bottom and the sections were numbered as nos. 1-5 and -1 to -5 from the center of the chamber where the larvae were first installed. Light was directed from the side of section no. 5 under the light condition. The proportions of larvae were calculated using the overall data for all of the larval stages. The equation of the calculation is as follows: (number of larvae found in the designated section)/(number of larvae used for all experiments). 
の 2 区画に集中して分布した（Fig. 2)。そこで，本研 究では, 光源側に近い 3 区画に分布した幼生は正の反 応を, 逆に光源側から遠い 3 区画に分布した幼生は負 の反応を示したものとし，それら幼生の割合に及ぼす光 量と齢期の影響を解析した。解析には一般化線形混合効 果モデル (generalized linear mixed effects model, GLMM $)^{27)}$ を用い, 応答変数を正あるいは負の反応率 (反応個体数, 非反応個体数), 説明変数を処理区と齢期 とし，䛊差構造に二項分布を指定した。また，各試行は 同日・同時刻に実施していないことから，その影響をラ ンダム効果として GLMM 解析に取り組むこととし，各 試行の通し番号を変量効果として指定した。解析には lme4 パッケージの glmer 関数 ${ }^{29)}$ を用い, car パッケー ジの Anova 関数 30 による Wald $\chi^{2}$ test を適用して説明 变数の効果を検定した。鉛直分布に関する実験では, 縦 型実験容器の 8 区画に下から 1-8の番号を振り, 暗黒 区と光照射区で同日齢の幼生が分布する区画番号の差を Welch の $t$ 検定により比較した。測定した形態のうち, 甲幅, 甲高, 側棘長, 背額棘長, 触角長, 第 1 - 第 2 顎脚外肢長と基節長, 総遊泳毛長については甲長に対す る比を, 腹部の全面積については甲長の 2 乗值に対す る比を求め, 各顎脚の遊泳毛数と平均遊泳毛長について は計測值を用い, pairwise $t$ 検定により齢期間で多重比 較を行った。

\section{結果}

走光性 光量別 - 波長別実験とも, 処理区と齢期は, 幼生の正抢よび負の反応率に有意な影響を及ぼした (Table 1)。

光量別実験では，Z1 では正の反応率が 0.0031-0.31 $\mu \mathrm{mol} \mathrm{m}{ }^{-2} \mathrm{~s}^{-1}$ にかけて上昇し，それ以上の区では平均 0.6 前後で推移した (Fig. 3)。一方, 負の反応率は正の 反応とは逆に， $0.0031 \mu \mathrm{mol} \mathrm{m}^{-2} \mathrm{~s}^{-1}$ でピーク（平均 0.75）を示して $0.31 \mu \mathrm{mol} \mathrm{m}{ }^{-2} \mathrm{~s}^{-1}$ にかけて減少し，そ れ以上の区では 0.2 前後で推移した。Z $\mathrm{Z} 2$ になると, Z 1 に比較して正の反応は弱く, 逆に負の反応は強くなり,
正の反応率は $0.31 \mu \mathrm{mol} \mathrm{m}{ }^{-2} \mathrm{~s}^{-1}$ 以上では 0.3 前後, 負 の反応率は $0.0031 \mu \mathrm{mol} \mathrm{m}^{-2} \mathrm{~s}^{-1}$ では 1 に達し， 0.031 $\mu \mathrm{mol} \mathrm{m}{ }^{-2} \mathrm{~s}^{-1}$ で 0.7 , それ以上では 0.4 前後で推移した。 Z3 とZ4 になると, 正の反応の弱化と負の反応の強化 がさらに進み, 光照射区では光量に関わらず正の反応を 示す個体は少なく, 多くの個体が負の反応を示した。 Z5 では, Z3 とZ4よりも正の反応率は高く, $31 \mu \mathrm{mol}$ $\mathrm{m}^{-2} \mathrm{~s}^{-1}$ で 0.3 を示すとともに, 負の反応率は全体的に Z1 程度まで低下した。MGでは，ゾエア期に比較する と, 総じて正打よび負の反応とも弱かった。一方, C1 では, 正の反応が強くみられ, 負の反応は弱いか, みら れなかった。

波長別実験では, 光量別実験と同様の光に対する正お よび負の反応がみられ，正の反応率は Z1 から Z3・Z4 にかけて低下し，Z5 でやや増加してC1 では高い值を 示した (Fig. 4)。一方, 負の反応率は Z1 から Z3・Z4 にかけて高くなり，Z5 と MGでは低下して，C1では 検出されなかった。波長に対する反応をみると，Z1$\mathrm{MG}$ では負の反応率が $620 \mathrm{~nm}$ 以上の長波長で特に高く なる傾向を示した。

鉛直分布 ふ化直後打よびふ化当日の幼生は, 明暗条 件に関わらず, 緹型容器の底から 4 番目の区画以上の 層に分布したが，それ以降は明暗条件・昼夜によらず底 から 3 番目以下の層に分布した (Fig. 5)。同日齢の明 暗条件で幼生の分布位置に有意な差は認められなかった $(P=0.177-1.00)$ 。

沈降速度亡体密度 通常海水中（比重 1.025）に打け るふ化直後の幼生の平均沈降速度は $3.9 \mathrm{~mm} \mathrm{~s}^{-1}$ であっ たが， 2 日齢にかけて $7.6 \mathrm{~mm} \mathrm{~s}^{-1}$ まで増加した（Fig. 6)。それ以降，ゾエア期間中の沈降速度は直線的に増 大して 27 日齢（Z5）には $22.8 \mathrm{~mm} \mathrm{~s}^{-1}$ に達した。沈降 速度は $\mathrm{MG}$ へ変態した直後（29日齢）には $19.7 \mathrm{~mm}$ s s $^{-1}$ 示し，その後増加して 36-50 日齢には 33.0-36.5 $\mathrm{mm} \mathrm{s}^{-1}$ で推移し， $\mathrm{C} 1$ への脱皮直後（49 日齢）には再 び減少して $24.1 \mathrm{~mm} \mathrm{~s}^{-1}$ であった。

幼生の平均体密度はふ化直後には $1.051 \mathrm{~g} \mathrm{~cm}^{-3}$ であ

Table 1 Analysis of deviance table by a Wald $\chi^{2}$ test (type II) to evaluate the effects of treatment and larval stage on the positive and negative phototactic behavior of larvae of the horsehair crab in the light intensity or light wavelength experiments

\begin{tabular}{|c|c|c|c|c|c|}
\hline Experiment & Response variable & Explanatory variable & $\chi^{2}$ & $D f$ & $P\left(>\chi^{2}\right)$ \\
\hline \multirow[t]{4}{*}{ Light intensity } & \multirow[t]{2}{*}{ Positive behavior } & Light treatment & 33.996 & 6 & $6.74 \times 10^{-6}$ \\
\hline & & Stage & 113.086 & 6 & $<2.2 \times 10^{-16}$ \\
\hline & \multirow[t]{2}{*}{ Negative behavior } & Light treatment & 64.401 & 6 & $5.72 \times 10^{-12}$ \\
\hline & & Stage & 110.637 & 6 & $<2.2 \times 10^{-16}$ \\
\hline \multirow[t]{4}{*}{ Light wavelength } & \multirow[t]{2}{*}{ Positive behavior } & Light treatment & 60.421 & 15 & $2.14 \times 10^{-7}$ \\
\hline & & Stage & 206.115 & 6 & $<2.2 \times 10^{-16}$ \\
\hline & \multirow[t]{2}{*}{ Negative behavior } & Light treatment & 73.253 & 15 & $1.17 \times 10^{-9}$ \\
\hline & & Stage & 100.952 & 6 & $<2.2 \times 10^{-16}$ \\
\hline
\end{tabular}


a) $\mathrm{Z1}$

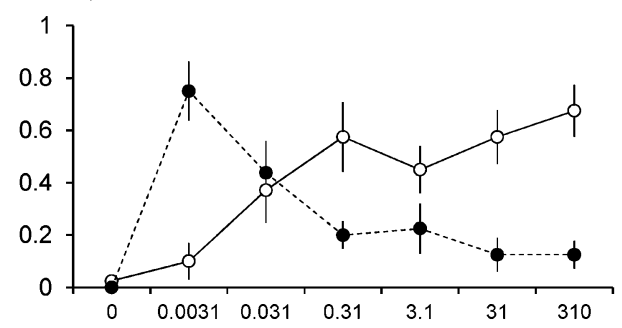

b) $\mathrm{Z2}$ e) $Z 5$

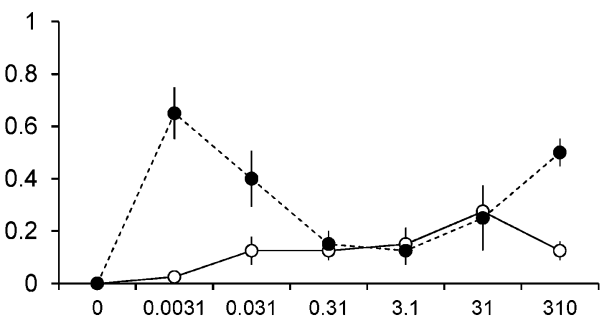

f) $M G$

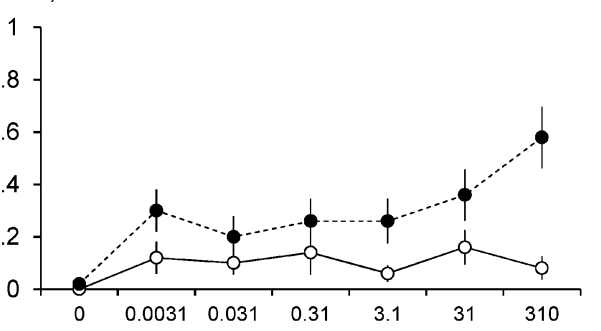

g) $\mathrm{C} 1$

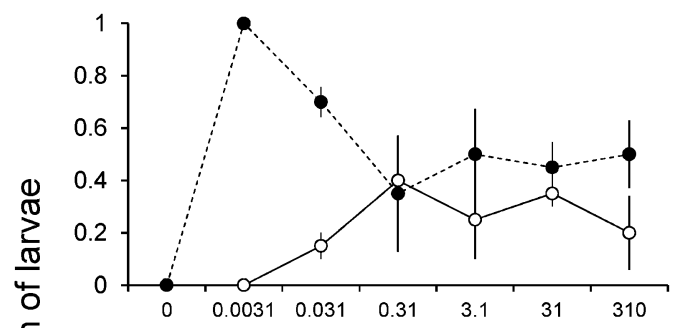

c) Z3
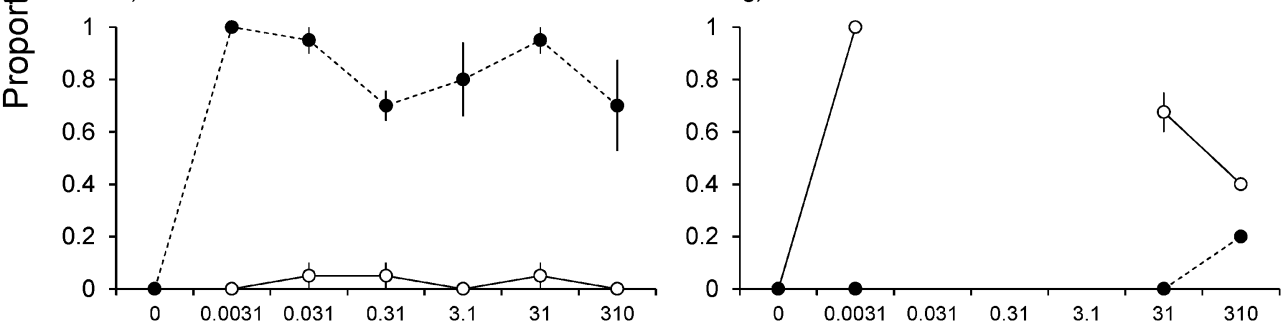

d) $Z 4$

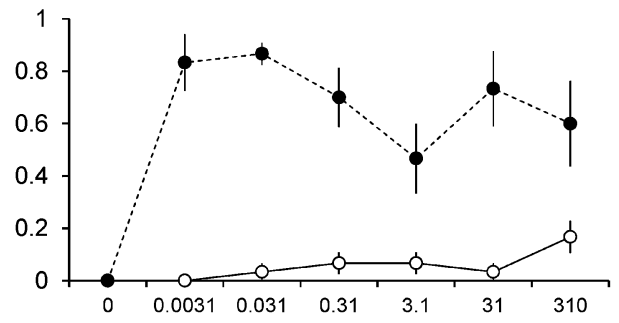

Light intensity $\left(\mu \mathrm{mol} \mathrm{m} \mathrm{m}^{-2} \mathrm{~s}^{-1}\right)$

Fig. 3 Ontogeny of the behavioral response of the horsehair crab larvae to different light intensities in the horizontal test chamber ( $O$, larvae found in the three sections near the light source; $\bullet$, larvae found in the three sections far from the light source). a-e, First to fifth zoeal stages (Z1-Z5); f, megalopal stage (MG); g, first crab stage (C1). Symbols and vertical bars show the means and standard errors of replicate samples, respectively. Number of replications: Z1 (0-5 days after hatching [DAH]), 7-8; Z2 (7, $10 \mathrm{DAH}), 4$; Z3 (11, $13 \mathrm{DAH}), 4$; Z4 (16-20 DAH), 6; Z5 (22-28 DAH), 8; MG (31-50 DAH), 10; C1 (50, 51 DAH), 2. Five larvae were used for each replication.

ったのが，1日齢には $1.082 \mathrm{~g} \mathrm{~cm}^{-3}$ へ増加した（Fig. 6)。それ以降の体密度は，脱皮に伴い同様に増減する 傾向が反られたが，大きく変動することはなく，1.080 $\mathrm{g} \mathrm{cm}^{-3}$ 前後で推移した。MG へ変態直後（29 日齢）の 体密度は $1.063 \mathrm{~g} \mathrm{~cm}^{-3}$ であったが，その後増加して 44 日齢には最大值 $1.148 \mathrm{~g} \mathrm{~cm}^{-3}$ に達した。C 1 へ脱皮直後 (49 日齢) の体密度は $1.084 \mathrm{~g} \mathrm{~cm}^{-3}$ であった。

外部形態 幼生の体の基本構造に関わる甲幅と甲高の 甲長に対する比抢よび腹部面積の甲長の 2 乗値に対す る比は, 齢期によって変化しなかった（Table 2)。頭胸
甲の突起状の部位長, すなわち側棘長, 背棘長および触 角長の甲長に対する比は，それぞれ Z4, Z3 抢よびZ2 にかけて Z1 の 35\%, 65\% 拈よび $80 \%$ 程度まで有意に 低下した。遊泳器官である第 1 - 第 2 顎脚の外肢長比々 基節長比は Z4 にかけて低下する傾向を示し, 前者では Z1 の $85 \%$ 程度, 後者では $75 \%$ 程度の值を示した。一 方, 遊泳毛数は Z1 の 4 本から Z2 の 12 本まで急激に増 加し, 以降脱皮ごとに 2-3 本ずつ増加した。遊泳毛 1 本の平均的長さは $Z 1$ で最大であったが, 総遊泳毛長比 は, 毛数の増加によって Z2 にかけて有意に増加し, そ 
a) $Z 1$

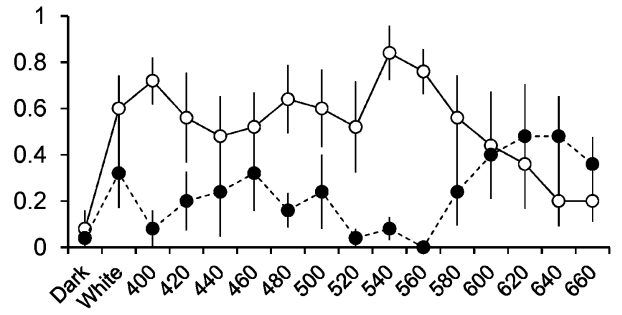

b) Z2

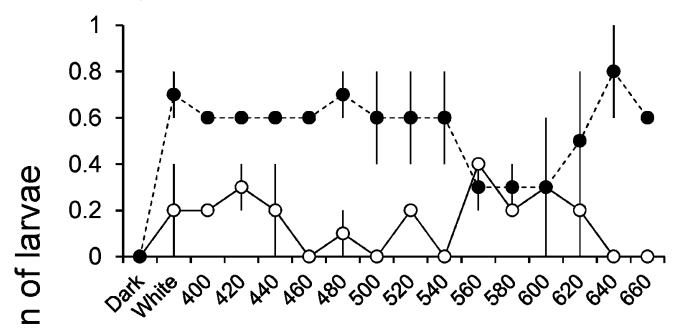

c) Z3

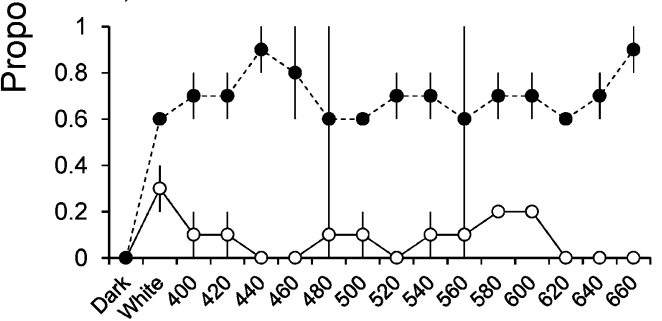

d) $Z 4$

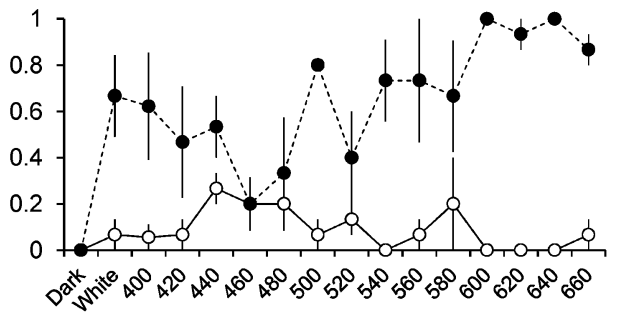

e) $Z 5$

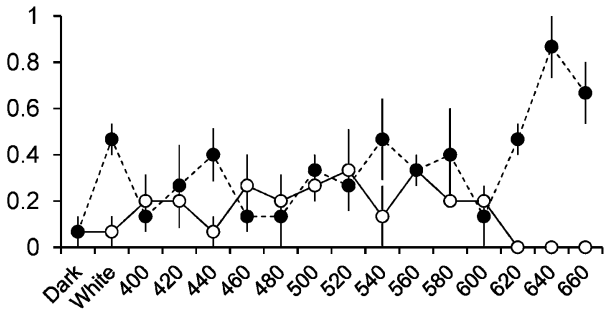

f) $M G$

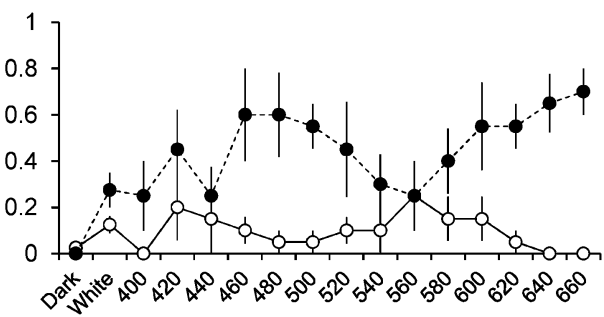

g) $\mathrm{C} 1$

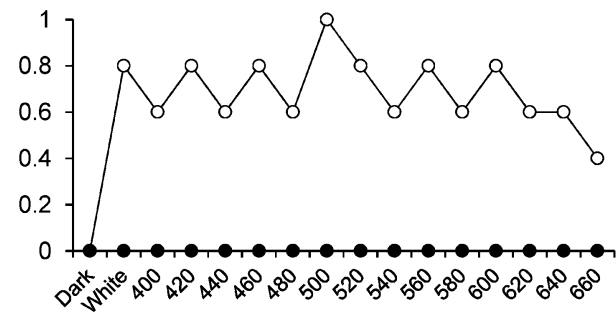

\section{Light condition and wavelength $(\mathrm{nm})$}

Fig. 4 Ontogeny of the behavioral response of the horsehair crab larvae to different light wavelengths, the white light condition $\left(1.5 \mu \mathrm{mol} \mathrm{m}^{-2} \mathrm{~s}^{-1}\right)$ and the dark condition in the horizontal test chamber $(\mathrm{O}$, larvae found in the three sections near the light source; $\bullet$, larvae found in the three sections far from the light source). a-e, First to fifth zoeal stages (Z1-Z5); f, megalopal stage $(\mathrm{MG})$; $\mathrm{g}$, first crab stage $(\mathrm{C} 1)$. Symbols and vertical bars show the means and standard errors of replicate samples, respectively. Number of replications: Z1 (0-5 DAH), 5; Z2 (7, 9 DAH), 2; Z3 (12, 14 DAH), 2; Z4 (17-21 DAH), 3; Z5 (23-27 $\mathrm{DAH}), 3$; MG (30-46 DAH), 4-8; C1 (50 DAH), 1. Five larvae were used for each replication.

れ以降 Z1 の 2 倍前後で推移した。腹肢原基長比は齢期 に伴い有意に大きくなり, Z5 では Z1の 7.7 倍に達した が，甲長に対する比は 0.25 程度で小さかった。

\section{考察}

十脚甲殼類幼生に抢ける体密度の個体発生を研究した 事例は少なく，わずかに飼育したイセエビ Panulirus japonicus のフィロソーマ幼生 $(0-312 \text { 日齢 })^{31}$ 扰よびヤ シガニの Z1-Z4 と MG $\left.{ }^{17}\right)$ で調査されているに過ぎな い。イセエビフィロソーマ幼生の体密度は基本的に大き
く変化することはなく, ふ化から最終齢フィロソーマの 平均体密度は $1.097 \mathrm{~g} \mathrm{~cm}^{-3}$ であったことが報告されて いる。 ${ }^{31)}$ 一方, ヤシガ二幼生の体密度は Z1-Z3 で 1.086$1.089 \mathrm{~g} \mathrm{~cm}^{-3}$ であり, Z4 と MG で 1.072-1.075 $\mathrm{g} \mathrm{cm}^{-3}$ まで減少したことが報告されている。17) ヤシガニは MG 期に貝殼に入り陸上生活に移行することから，この体密 度の減少は海水よりも粘性の低い媒体（空気）で生活す る際のエネルギー消費を抑える効果があるものと推察さ れている。17) 本研究のケガニ幼生の体密度は, ゾエア期 間中は $1.080 \mathrm{~g} \mathrm{~cm}^{-3}$ 前後で推移したが, MG では最大 


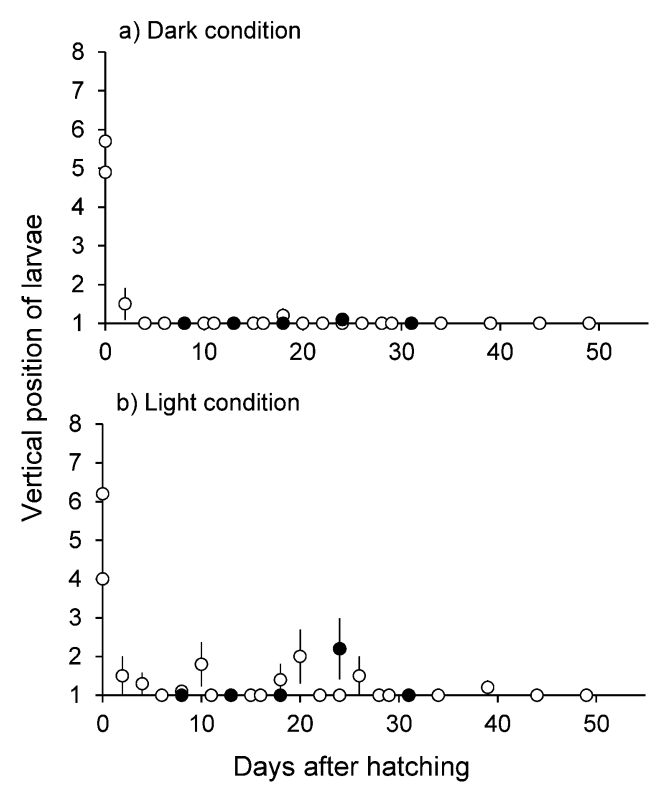

Fig. 5 Ontogeny of the behavioral response of the horsehair crab larvae to dark condition (a) and light condition $\left(3.1 \mu \mathrm{mol} \mathrm{m}^{-2} \mathrm{~s}^{-1}\right)$ (b) in the vertical test chamber during the daytime $(\mathrm{O})$ and nighttime $(\bullet)$. The vertical test chamber was marked at $10-\mathrm{cm}$ intervals and a number (1-8) was given to each section from the bottom of the chamber. Symbols and vertical bars show the means and standard errors of replicate samples, respectively $(n=10)$. One larva was used for each replication.
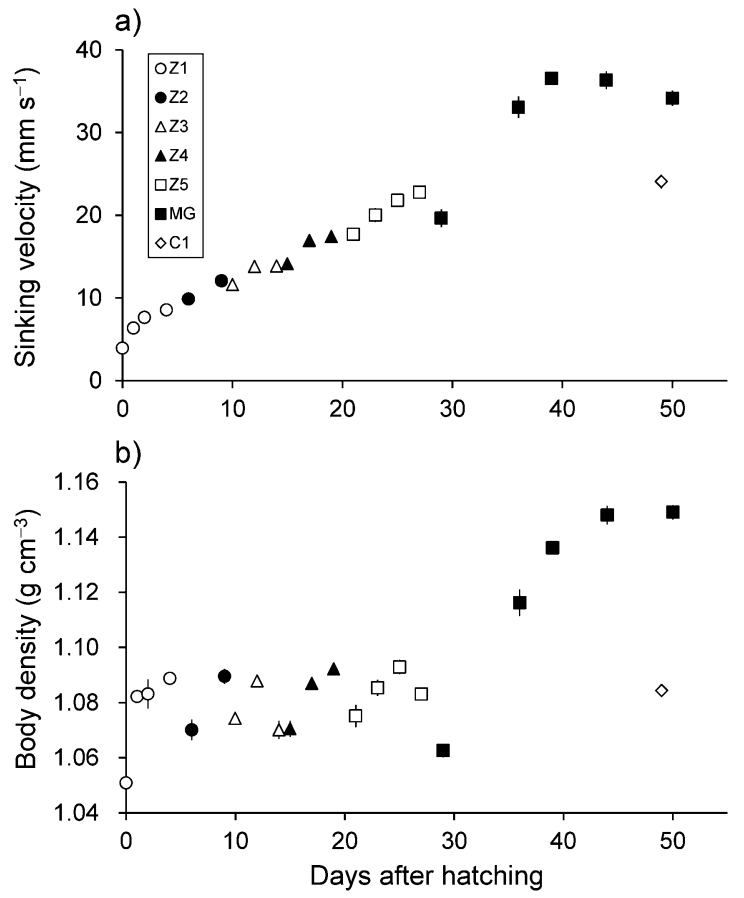

Fig. 6 Changes in the mean values of the sinking velocity (a) and body density (b) of the horsehair crab larvae at the first to fifth zoeal stages (Z1-Z5), megalopal stage (MG) and first crab stage (C1). Symbols and vertical bars show the means and standard errors of replicate samples, respectively $(n=10)$. One larva was used for each replication.

Table 2 Ontogenetic changes of morphological characters in zoeal larvae of the horsehair crab reared in the laboratory

\begin{tabular}{|c|c|c|c|c|c|}
\hline Morphological characteristic & First zoea & Second zoea & Third zoea & Fourth zoea & Fifth zoea \\
\hline Carapace width* & $0.893 \pm 0.029^{a}$ & $0.950 \pm 0.027^{\mathrm{a}}$ & $0.962 \pm 0.031^{\mathrm{a}}$ & $0.949 \pm 0.006^{\mathrm{a}}$ & $0.969 \pm 0.013^{\mathrm{a}}$ \\
\hline Carapace height* & $0.956 \pm 0.044^{\mathrm{a}}$ & $0.954 \pm 0.042^{\mathrm{a}}$ & $0.980 \pm 0.021^{\mathrm{a}}$ & $0.959 \pm 0.023^{\mathrm{a}}$ & $1.022 \pm 0.024^{\mathrm{a}}$ \\
\hline Total length of lateral spines* & $0.858 \pm 0.052^{\mathrm{a}}$ & $0.592 \pm 0.007^{b}$ & $0.418 \pm 0.018^{c}$ & $0.308 \pm 0.013^{\mathrm{d}}$ & $0.299 \pm 0.017^{\mathrm{d}}$ \\
\hline Total length of dorsal and ventral spines* & $2.268 \pm 0.088^{\mathrm{a}}$ & $1.848 \pm 0.089^{\mathrm{ab}}$ & $1.669 \pm 0.063^{\mathrm{b}}$ & $1.380 \pm 0.051^{\mathrm{b}}$ & $1.612 \pm 0.207^{\mathrm{b}}$ \\
\hline Total length of antennal processes* & $0.999 \pm 0.032^{\mathrm{a}}$ & $0.814 \pm 0.035^{\mathrm{b}}$ & $0.821 \pm 0.033^{\mathrm{b}}$ & $0.777 \pm 0.025^{b}$ & $0.862 \pm 0.032^{\mathrm{b}}$ \\
\hline Exopod length of maxilliped $1(\mathrm{mx} 1)^{*}$ & $0.478 \pm 0.022^{\mathrm{a}}$ & $0.471 \pm 0.023^{\mathrm{ab}}$ & $0.454 \pm 0.011^{\mathrm{abc}}$ & $0.400 \pm 0.008^{c}$ & $0.406 \pm 0.012^{b c}$ \\
\hline Basis length of $m x 1^{*}$ & $0.481 \pm 0.021^{\mathrm{a}}$ & $0.469 \pm 0.013^{\mathrm{ab}}$ & $0.420 \pm 0.012^{\mathrm{bc}}$ & $0.365 \pm 0.007^{\mathrm{d}}$ & $0.385 \pm 0.006^{\mathrm{cd}}$ \\
\hline Number of natatory setae of mx1 & $4.0 \pm 0.0^{\mathrm{a}}$ & $11.8 \pm 0.2^{\mathrm{b}}$ & $14.4 \pm 0.5^{c}$ & $16.2 \pm 0.6^{\mathrm{d}}$ & $18.2 \pm 0.2^{\mathrm{e}}$ \\
\hline Average length of natatory setae of $\mathrm{mx} 1(\mathrm{~mm})$ & $0.762 \pm 0.009^{\mathrm{a}}$ & $0.537 \pm 0.015^{\mathrm{b}}$ & $0.569 \pm 0.017^{\mathrm{bc}}$ & $0.609 \pm 0.015^{c}$ & $0.619 \pm 0.011^{\mathrm{c}}$ \\
\hline Total length of natatory setae of $m \times 1^{*}$ & $2.508 \pm 0.073^{\mathrm{a}}$ & $4.619 \pm 0.162^{\mathrm{b}}$ & $5.132 \pm 0.129 \mathrm{bc}$ & $4.611 \pm 0.182^{\mathrm{b}}$ & $5.323 \pm 0.177^{\mathrm{c}}$ \\
\hline Exopod length of maxilliped $2(\mathrm{mx} 2)^{*}$ & $0.487 \pm 0.025^{\mathrm{a}}$ & $0.489 \pm 0.005^{\mathrm{a}}$ & $0.465 \pm 0.013^{\mathrm{ab}}$ & $0.429 \pm 0.016^{\mathrm{ab}}$ & $0.414 \pm 0.010^{\mathrm{b}}$ \\
\hline Basis length of $\mathrm{mx} 2^{*}$ & $0.550 \pm 0.019^{\mathrm{a}}$ & $0.504 \pm 0.019^{\mathrm{ab}}$ & $0.482 \pm 0.012^{\mathrm{b}}$ & $0.427 \pm 0.009^{c}$ & $0.408 \pm 0.007^{c}$ \\
\hline Number of natatory setae of $\mathrm{mx} 2$ & $4.0 \pm 0.0^{\mathrm{a}}$ & $12.0 \pm 0.3^{\mathrm{b}}$ & $15.6 \pm 0.4^{\mathrm{c}}$ & $18.6 \pm 0.2^{\mathrm{d}}$ & $20.4 \pm 0.6^{\mathrm{e}}$ \\
\hline Average length of natatory setae of $\mathrm{mx} 2(\mathrm{~mm})$ & $0.798 \pm 0.009^{a}$ & $0.580 \pm 0.014^{b}$ & $0.630 \pm 0.035^{b}$ & $0.670 \pm 0.021^{\mathrm{b}}$ & $0.649 \pm 0.027^{b}$ \\
\hline Total length of natatory setae of $\mathrm{mx} 2 *$ & $2.626 \pm 0.097^{\mathrm{a}}$ & $5.074 \pm 0.225^{\mathrm{b}}$ & $6.141 \pm 0.246^{c}$ & $5.827 \pm 0.199 \mathrm{bc}$ & $6.328 \pm 0.355^{c}$ \\
\hline Pleopod length* & $0.033 \pm 0.045^{\mathrm{a}}$ & $0.064 \pm 0.004^{\mathrm{b}}$ & $0.100 \pm 0.007^{c}$ & $0.188 \pm 0.005^{\mathrm{d}}$ & $0.251 \pm 0.016^{\mathrm{e}}$ \\
\hline Abdomen area** & $0.560 \pm 0.072^{\mathrm{a}}$ & $0.584 \pm 0.038^{\mathrm{a}}$ & $0.586 \pm 0.025^{\mathrm{a}}$ & $0.442 \pm 0.024^{\mathrm{a}}$ & $0.471 \pm 0.008^{\mathrm{a}}$ \\
\hline
\end{tabular}

See Fig. 1 for morphological features.

Data: mean \pm standard error $(n=5)$.

* Values are shown as the ratio to carapace length. ${ }^{* *}$ Values are shown as the ratio to the square of carapace length.

Different superscript letters indicate significant differences between stages in the same line $(p<0.05)$. 
$1.148 \mathrm{~g} \mathrm{~cm}^{-3}$ に増加した。ケガニ幼生は $\mathrm{MG}$ 期に沿岸 で底生生活に移行することから, ${ }^{32)}$ 体密度の大幅な増加 は海水流動の激しい沿岸域での底生生活に対する適応現 象かもしれない。

甲殼類幼生の体重, 水分, 元素 (炭素, 水素, 窒素) 含有量は同一齢期内でも脱皮周期により変化することが 知られている。16) 例えば, アサヒガニ Ranina ranina 幼 生では, 各齢期の脱皮当日の水分含量は前齢期の最終日 より高くなるが，逆に炭素抢よび窒素含量は減少するこ とが報告されている。33) ケガニ幼生の体密度も脱皮周期 により変化する傾向がみられ，脱皮後に減少した。今回 脱皮当日に測定した $\mathrm{C} 1$ の体密度は $1.084 \mathrm{~g} \mathrm{~cm}^{-3}$ であ り, 前日の $\mathrm{MG}$ より大幅に減少したが, C1 以降も引き 続き底生生活を送ることから，その体密度は脱皮周期に 伴い少なくとも MG と同レベルに達するものと予想さ れる。

本研究では, ケガニゾエア幼生の体サイズ, 打よび遊 泳能力と沈下抵抗に関わると考えられる外部形態を計測 したところ, 体の基本的な構造は脱皮龄によって変化し なかった。一方, 頭胸甲の突起状部位および第 1 ・第 2 顎脚の外肢長と基節長の甲幅に対する比は発育に伴い縮 小する傾向を示した。また, 腹肢原基は発育に伴い発達 した。MGでは背額棘や側棘が退化・消失し, 顎脚は大 きく変化して口器として, また腹肢が遊泳器官として機 能するようになることから,16)このようなゾエアの体形 の変化は $\mathrm{MG} へ$ の変態に向けたものと解釈できる。ケ ガニゾエア幼生は顎脚の遊泳毛を運動させて遊泳・移動 する。34) また，遊泳毛の運動を停止させて頭部から鉛直 下向きに大きく降下する動きや腹筋を急速に収縮させる ことによって背後方向に大きく進む動きを示すことが知 られている。34) ケガニゾエア幼生の突起状部位が実際に どの程度の抗力発生に寄与しているのか, 現段階では不 明であるが，少なくとも頭胸甲の突起状部位の縮小は沈 下抵抗を減少させる方向に働くものと考えられる。一 方, 顎脚の遊泳毛は Z1 からZ2 にかけて大幅に増加し たが，それ以降の総遊泳毛長比は変化しなかった。した がって, ケガニゾエア幼生は発育に伴い沈下抵抗を減少 させるものの, Z1 から Z 2 にかけて遊泳能力を大幅に 向上させ, それ以降にはその能力を維持するものと推察 される。ケガニ幼生の体密度は通常の海水比重 (1.025) よりも大きく, 麻酔した幼生は海水中で沈下した。ま た, 沈下速度は発育に伴い直線的に増大したが,これは 総体重の増加抢よび沈下抵抗の減少によるものと推察さ れる。以上のことから, ケガニのゾエア幼生が静水中で 浮遊するためには, 顎脚遊泳毛や腹部屈曲によって運 動・遊泳することが必須である。

本研究では, 水平容器に収容したケガニ幼生の遊泳移 動が横方向からの光刺激によって惹起されることが明ら
かとなった。ケガニの Z1 は強い光に対して正の反応 を, 弱い光に対して負の反応を示し, それらの反応曲線 はカニ類 13 種とヤドカリ類 2 種の Z 1 で報告された反 応曲線10-12) に類似していた。ミナトオウキガニ Rhithropanopeus harrisii では, 幼生の光刺激に対する反 応はゾエア期間中には変化しないが，MGでは反応しな くなることが知られている。10,13) また，ヤシガニでは光 刺激に対する負の反応はほとんどみられていない。17)一 方, 本研究でケガニの Z3 と Z4 は光刺激に対して強い 負の反応を示し, 正の反応は示さなかった。また，Z5 と MG では光刺激に対する反応は弱くなり，C1 では強 い正の反応のみが認められた。このように, 光刺激に対 する十脚甲殼類幼生の反応は種によって異なるようであ る。さらに，十脚甲殼類幼生の光波長に対する反応につ いては, これまで正の反応を惹起する光量で試験されて 抢り,10-14) 負の反応を示寸波長については明らかにされ ていなかったが，ケガニの Z1-MG では $620 \mathrm{~nm}$ 以上の 長波長で負の反応が特に強くなることが明らかとなった。

本研究では, ケガニ幼生の鉛直分布についても調査し たところ，明暗条件に関わらずふ化当日の Z 1 は浮遊し たが，それ以降にはほとんどの個体が沈降した。しか し, 前報18)の研究で, $500 \mathrm{~L}$ 容量の黑色水槽と透明水槽 抢よび水槽底の直上で長方形の翼を回転させて飼育水を 攪汼する装置の有無を組み合わせてケガニ幼生の飼育試 験を行ったところ, 攪找装置によるケガニ幼生の浮上効 果は認められなかったものの, 幼生は夜間には水槽内で 分散する傾向を示した。これは, 水槽内ではエアースト ンによる通気によって飼育水が流動しており, 暗黒下で 光刺激に反応しない幼生が飼育水とともに還流した結果 であろうと推察される。一方, 水槽の下層に分布する幼 生の割合 (沈降率) は発育に伴い高くなり, 総じて夜間 より昼間に高く, 特に透明水槽で高い傾向がみられた。 な抢, Z5 になると, 昼夜の沈降率の差は縮小寸る傾向 を示した。また, 飼育水中の光量は, 上方向から光が入 射する黒色水槽では水深に比例して減少したが, 横方向 からの光も入射する透明水槽では中層々下層で大きい值 を示した。したがって, 負の走光性が強い Z2-Z4 は, 昼間には光刺激によって下層に沈降し, 特に光が上面と 横方向から入射する透明水槽でその反応が強く現れたも のと考えられる。一方, 光に対する反応が弱いZ 25 に打 いて, 昼夜によらず沈降率が高かったのは, 成長した Z5 を分散させるほどの飼育水の流動がなかったことに よるものと推察される。

本研究で明らかにしたケガニ幼生の光刺激に対する反 応から, $620 \mathrm{~nm}$ 以上の長波長の照射によって幼生の行 動を制御し, 水槽内で浮遊させることが可能になるかも しれない。それを検証するには, まず縦型容器の下側か ら照射した長波長に対する幼生の反応を調査する必要が 
ある。さらには, 飼育水槽内でゾエア幼生を浮遊分散さ せる方法として, 光刺激のない暗黒条件で飼育する方法 が考えられる。力二類幼生は暗黒条件下でも拱䭒するこ とが可能で， 24 時間暗期の飼育条件下にお污幼生の 生残率はアサヒガニでは低下するが, ${ }^{35)}$ Australia giant crab Pseudocarcinus gigas では明期を 6-24 時間に設定し た場合と有意差が認められなかったことが報告されてお り, ${ }^{36)}$ 光周期がカ二類幼生の生残や発育に及ぼす影響は 種によって異なる。ケガニ幼生を飼育水中に分散させて 飼育する方法を開発するには, 今後光周期や長波長が幼 生の生残と発育に及ぼす影響を調査するとともに, 飼育 水の還流方法についても検討する必要がある。

\section{謝辞}

本研究を進めるにあたり, 室蘭, いぶり噴火湾, 長万 部, 八雲, 森, 落部, 佐原の各漁業協同組合には抱卵雌 の特別採捕にご理解とご配慮を頂いた。また長万部漁業 協同組合の伊藤恵造氏, 長間馨一氏, 蛇川松夫氏には抱 卵雌の捕獲にご尽力いただいた。ここに記して感謝申し 上げる。また, 幼生の体密度測定方法ついて想切丁寧な るご教示を頂いた近畿大学の坂本 亘教授と高志利宣研 究員 (いずれも当時)に心より打礼申し上げる。さらに, 実験にご協力頂いた水産総合研究センターの村上直人 氏, 森岡泰三氏, 作業を補佐して頂いた橋本志満子, 山 本朋美, 奥泉美智子, 鈴木裕子, 武田佐奈汇の各氏に厚 く打礼申し上げる。また，本論文をまとめるにあたり有 益な助言を頂いた同センターの薄 浩則部長と鵜沼辰哉 グループ長, 並びに原稿に対して有益なコメントを頂い た 2 名の查読者に深謝する。

\section{文献}

1）三原栄次.ケガニ.「漁業生物図鑑新北のさかなたち」 （上田吉幸, 前田圭司, 嶋田 宏, 鷹見達也編) 北海道新 聞社，札幌. 2003; 380-385.

2）平成 15 年北海道水産現勢（北海道区水産研究所編）. 北 海道水産部, 札幌. 2005.

3）熊谷厚志. ケガニの種苗生産. 平成 6 年度日本栽培漁業 協会事業年報, 社日本栽培漁業協会, 東京. 1996; 194197.

4）熊谷厚志. ケガニの種苗生産. 平成 7 年度日本栽培漁業 協会事業年報, (社)日本栽培漁業協会, 東京. 1997; 211214.

5）神保忠雄, 浜崎活幸, 芦立昌一. ケガ二幼生の生残, 発 育および摂䬣に及ぼすアルテミア給餌密度の影響. 日本 水産学会誌 2005; 71: 563-570.

6）神保忠雄, 浜崎活幸, 芦立昌一. ケガニ幼生の生残, 発 育および摂餌に及ぼす水温の影響. 日本水産学会誌 2007; 73: 1081-1089.

7）神保忠雄, 浜崎活幸, 芦立昌一. ケガニ幼生の生残, 発 育および摂餌に及ぼす塩分の影響. 日本水産学会誌 2012; 78: 405-412.

8）浜崎活幸, 小金隆之, 神保忠雄, 團 重樹. 力二類の種 苗生産技術：大量死亡とその防除. 日本水産学会誌
2006; 72: 263-266.

9）小金隆之, 浜崎活幸, 團 重樹. ズワイガニ種苗生産に おける飼育水の攪汼と薬浴による生残率の向上. 日本水 産学会誌 2007; 73: 226-232.

10) Forward RB Jr. Negative phototaxis in crustacean larvae: possible functional significance. J. Exp. Mar. Biol. Ecol. 1974; 16: 11-17.

11) Forward RB Jr. Occurrence of shadow response among brachyuran larvae. Mar. Biol. 1977; 39: 331-341.

12) Forward RB Jr. Comparative study of crustacean larval photoresponses. Mar. Biol. 1987; 94: 589-595.

13) Forward RB Jr, Costlow JD Jr. The ontogeny of phototaxis by larvae of the crab Rhithropanopeus harrisii. Mar. Biol. 1974; 26: 27-33.

14) Forward RB Jr, Cronin TW. Spectral sensitivity of larvae from intertidal crustaceans. J. Comp. Physiol. 1979; 133: 311-315.

15) Sulkin SD. Behavioral basis of depth regulation in the larvae of brachyuran carbs. Mar. Ecol. Prog. Ser. 1984; 15: 181-205.

16) Anger K. The biology of decapod crustacean larvae. AA Balkema Publishers, Rotterdam. 2001.

17) Hamasaki K, Sugimoto A, Sugizaki M, Murakami Y, Kitada S. Ontogeny of sinking velocity, body density, and phototactic behaviour in larvae of the coconut crab Birgus latro: implications for larval dispersal and recruitment in the sea. J. Exp. Mar. Biol. Ecol. 2013; 442: 58-65.

18）市川 卓, 村上直人, 森岡泰三, 村上恵祐, 浜崎活幸. ケガニ種苗生産に打ける光環境が幼生の沈降と発育に及 ぼす影響. 水産増殖 2014; 62: 65-73.

19）塩澤 聡, 竹内宏行, 廣川 潤. カンパチ種苗生産方法 の改良. 栽培技術研究報告 $2003 ; 31$ : 11-18.

20）照屋和久, 浜崎活幸, 橋本 博, 片山俊之, 平田喜郎, 鶴岡廣哉, 林 知宏, 虫明敬一. カンパチ仔魚の成長に ともなう体密度と水槽内鉛直分布の変化. 日本水産学会 誌 2009; 75: 54-63.

21）坂本 亘, 岡本杏子, 上土生起典, 家戸敬太郎, 村田 修. クロマグロ仔魚の成長に伴う比重変化. 日本水産学 会誌 $2005 ; 71: 80-82$.

22）照屋和久, 與世田兼三. ク工仔魚の成長と生残に適した 初期飼育条件々大量種苗量産試験. 水産増殖 2006; 54: 187-194.

23) Furbish DJ, Arnold AJ. Hydrodynamical strategies in the morphological evolution of spinose planktonic foraminifera. Geol. Soc. Am. Bull. 1997; 109: 1055-1072.

24) Padisák J, Soróczki-Pintér É, Rezner Z. Sinking properties of some phytoplankton shapes and the relation of form resistance to morphological diversity of plankton an experimental study. Hydrobiologia 2003; 500: 243-257.

25) Nguyen H, Karp-Boss L, Jumars PA, Fauci L. Hydrodynamic effects of spines: a different spin. Limnol. Oceanogr. Fluid. Environ. 2011; 1: 110-119.

26) Miyake $Y$, Koizumi M. The measurement of the viscosity coefficient of sea water. J. Mar. Res. 1948; 7: 63-66.

27) Everitt BS, Hothorn T. A Handbook of Statistical Analyses Using R. CRC Press, New York, 2010.

28) R Development Core Team. R: A language and environment for statistical computing. R Foundation for Statistical Computing, Vienna, 2013.

29) Bates B, Maechler M, Bolker B. lme4: linear mixed-effects models using S4 classes. www.lme4.r-forge.r-project.org, 2012.

30) Fox J, Weisberg S. An R Companion to Applied Regression, 
Second Edition. Sage Publications, California, 2011.

31) Hamasaki K, Mizumoto Y, Jinbo T, Murakami K. Ontogenetic change of body density and shape of the phyllosoma larvae of the Japanese spiny lobster. J. Crust. Biol. 2012; 32: 395-404.

32）阿部晃治. 道東近海におけるケガニの初期生活. 水産海 洋研究会報 1977; 31: 14-19.

33) Minagawa M, Chiu JR, Murano M. Developmental changes in body weight and elemental composition of laboratory-reared larvae of the red frog crab, Ranina ranina (Decapoda: Brachyura). Mar. Biol. 1993; 116: 399-
406.

34）桑原久実, 水島敏博. オホーツク海に抢けるケガニ浮遊 幼生の動態に関する基礎的研究. 北海道水産試験場研究 報告 1999; 55: 69-77.

35) Minagawa M. Effects of photoperiod on survival, feeding and development of larvae of the red frog crab, Ranina ranina. Aquaculture 1994; 120: 105-114.

36) Gardner C, Maguire GB. Effect of photoperiod and light intensity on survival, development and cannibalism of larvae of the Australian giant crab Pseudocarcinus gigas (Lamarck). Aquaculture 1998; 165: 51-63. 